\title{
Pseudomonas veronii KJ mitigates flood stress-associated damage in Sesamum indicum $\mathbf{L}$.
}

\author{
Sajid Ali ${ }^{1} \cdot$ Muhammad Aaqil Khan ${ }^{1} \cdot$ Won-Chan Kim ${ }^{1}$ (B)
}

Received: 17 July 2018/ Accepted: 14 August 2018/Published online: 20 August 2018

(C) The Korean Society for Applied Biological Chemistry 2018

\begin{abstract}
Physiological characteristics of terrestrial plants are severely affected by waterlogging stress, leading to low photochemical efficiency of leaves and retarded growth and development. Plant growth-promoting rhizobacteria contain the acdS gene, which encodes for the enzyme 1-aminocyclopropane-1-carboxylate (ACC) deaminase. ACC deaminase cleaves the substrate ACC to produce $\alpha$ ketobutyrate and ammonia and mitigates the adverse effect of prolonged water stress. The aim of this study was to characterize ACC deaminase-producing rhizobacteria and evaluate their effects on sesame (Sesamum indicum L.) under waterlogging stress condition. The rhizobacterium Pseudomonas KJ was characterized on the basis of sequencing of the partial $1501 \mathrm{bp}$ fragment of 16S rDNA amplicon and confirmed as Pseudomonas veronii KJ. ACCsupplemented minimal medium revealed the phenotypic identification of acdS gene. The nucleotide sequence (1001 bp) of ACC deaminase gene of $P$. veronii $\mathrm{KJ}$ was also confirmed. We used $P$. veronii $\mathrm{KJ}$ as a bioinoculant in waterlogging stress and monitored the growth and developmental characteristics of sesame plants, including leaf chlorophyll fluorescence signals, concentration of chlorophyll, root and shoot length, and fresh and dry biomass in stressed versus unstressed plants. Plants treated with $P$. veronii $\mathrm{KJ}$ significantly $(P \leq 0.05)$ mitigated the waterlogging stress-related damage. Thus, the rhizobacterium Pseudomonas veronii $\mathrm{KJ}$ may be considered as a commendable addition to the consortium of beneficial microbes
\end{abstract}

Won-Chan Kim

kwc@knu.ac.kr

1 School of Applied Biosciences, College of Agriculture and Life Sciences, Kyungpook National University, Daegu 41566, Republic of Korea for its ability to reduce waterlogging stress-related damage in sesame plants.

Keywords ACC deaminase-producing and plant growthpromoting rhizobacteria $\cdot$ acd $S$ gene $\cdot$ Pseudomonas veronii $\mathrm{KJ} \cdot$ Sesamum indicum L. · Waterlogging stress

\section{Introduction}

Sesame (Sesamum indicum L.) is one of the most ancient cultivated oil crops in Asia and increasingly grown worldwide [1]. China, India, Nigeria, Tanzania, Myanmar, and Sudan are the top producers of black and white sesame and contribute to more than $60 \%$ of annual global supply of sesame seeds [2]. Sesame seeds may be directly used in different food items, as these contain $33-58 \%$ oil and $15-30 \%$ proteins. In addition, sesame seeds are known to exhibit various therapeutic compounds, including antioxidants (sesamin, sesamolin, sesaminol, and sesamolinol) and dietary fibers $[2,3]$. Optimization of cultivation factors such as water, fertilizers, and all biotic and abiotic stress conditions is essential to achieve high yields of sesame [4]. In particular, waterlogged condition during the early stage of cultivation is shown to hamper the growth and productivity of crops by up to $30 \%[1,4]$. Land plants become hypoxic or are oxygen deprived in waterlogged conditions, owing to the decrease in the oxygen diffusion into roots $[5,6]$. As healthy plants need soil oxygen concentrations above $0.1 \mathrm{~L} / \mathrm{L}$, waterlogged conditions may decrease the amount of oxygen, leading to the production of ethylene and accumulation of toxic compounds [5-7].

The gaseous hormone ethylene is found in all higher plants and greatly contributes to normal growth and 
development. In addition, ethylene is a key compound that plays an important role in the response of plants to a variety of stress conditions [8]. Under hypoxic condition, plants produce increased level of the enzyme 1-aminocyclopropane-1-carboxylic acid (ACC) synthase that converts the substrate $S$-adenosyl-L-methionine (SAM) to ACC, whereas the study of Lee et al. [9] demonstrated that recombinant ACC synthase can also convert SAM into ACC for the production of ethylene. Upon oxidation, the substrate ACC is converted to ethylene by ACC oxidase $[8,10]$. Higher concentrations of ethylene (stress ethylene) in plant tissues may adversely affect the physiological response of plants and initiate senescence, chlorosis, leaf abscission, growth inhibition, or even death [11].

Plant growth-promoting bacteria (PGPR) use different mechanisms to mitigate the damage induced by waterlogged stress and promote plant growth under stress conditions [12]. The bacteria found in near vicinity of plant roots and producing the enzyme ACC deaminase are of great importance. ACC deaminase cleaves ACC into ammonia and $\alpha$-ketobutyrate and reduces the level of stress ethylene [13]. Thus, bacterial ACC deaminase may play an important role by reducing the extremely high level of ethylene and alleviating damages caused by waterlogged stress in plants $[8,10]$.

Environmental stress conditions directly affect the photosynthetic machinery of plants; hence, fluorescence signals are widely used to estimate the activity of photosystem II under different environmental stress conditions [14]. The available literature strongly focuses on the use of chlorophyll fluorescence as a suitable tool for the assessment of environmental fitness and monitoring of photosynthetic events at different levels under abiotic stress conditions $[14,15]$. Plants respond to oxygen deficiency at different levels from the activation of signal transduction pathways to metabolic adaptation, leading to morphological changes and activation of other related strategies $[16,17]$. Several studies have demonstrated the adverse effect of waterlogging stress on major physiological functions of plants, and reduction in the concentration of chlorophyll, stomatal conductance, and biomass decline are the primary effects of waterlogging stress. These are often accompanied with the reduced $\mathrm{CO}_{2}$ assimilation, which confers an adverse effect on the growth and development of plants $[15,18]$.

To our knowledge, no study has attempted to study the effect of PGPR in sesame. However, the use of ACC deaminase-producing bacteria in waterlogged condition may significantly improve the concentration of chlorophyll and photochemical efficiency of leaves and increase the biomass of sesame plants.

\section{Materials and methods}

\section{Bacterial isolation and identification}

The rhizospheric bacterial strain $(\mathrm{KJ})$ was isolated from melon fields in Seongju, Republic of Korea. Morphological observations were reported based on the colony characteristics, and presumptive identification was performed on the basis of Bergey's Manual of Determinative Bacteriology [19]. For more efficient screening, the rhizobacterial isolate was purified by streaking several times onto nutrient agar plates and different tests such as oxidase, catalase, and Gram staining were performed. The selected rhizobacterial isolate was stored at $4{ }^{\circ} \mathrm{C}$ for further use.

\section{Screening of the bacterial isolate for the utilization of ACC as a nitrogen source}

The bacterial isolate was screened for its ability to utilize ACC as a sole nitrogen source in Dworkin and Foster (DF) minimal medium [20] according to the methods of Penrose and Glick [21] with some modifications. Two sets of DF minimal medium plates were prepared for the phenotypic identification of $a c d S$ gene. One set of plates was supplemented with ammonium sulfate $\left(\left(\mathrm{NH}_{4}\right)_{2} \mathrm{SO}_{4}, 2 \mathrm{~g} / \mathrm{L}\right)$, while the other set comprised a lawn of the substrate ACC $(3 \mathrm{mM})$. The selected bacterial culture was inoculated on to the medium plates and incubated at $28{ }^{\circ} \mathrm{C}$ for $4-5$ days.

\section{Direct amplification of 16S rDNA, sequencing, and homology analysis}

For the direct amplification of $16 \mathrm{~S}$ rDNA, the pure rhizobacterial strain was cultured on Luria-Bertani (LB) agar medium plate for $20-24 \mathrm{~h}$ at $28{ }^{\circ} \mathrm{C}$. Amplification of $16 \mathrm{~S}$ rDNA was carried out according to the method of Giovannoni et al. [22] with some modifications using a thermal cycler (Bio-Rad $\mathrm{T} 100^{\mathrm{TM}}$ ). The sequences of the oligonucleotide primers used for the amplification of 16S rDNA were as follows:

Forward primer 27F (5'AGAGTTTGATCMTGGCTC $\mathrm{AG}^{\prime}$ )

Reverse primer 1492R (5'TACGGYTACCTTGTTACG ACTT3') $^{\prime}$

Polymerase chain reaction (PCR) of $16 \mathrm{~S}$ rDNA from the isolate (positive for ACC deaminase activity) was performed in a final volume of $50 \mu \mathrm{L}$. The reaction mixture comprised $43 \mu \mathrm{L}$ of ultrapure water, $5 \mu \mathrm{L}$ of $10 \times$ PCR buffer, $1.0 \mu \mathrm{L}(10 \mathrm{mM})$ of each dNTP (dATP, dCTP, dGTP, and dTTP), $0.3 \mu \mathrm{L}(10 \mu \mathrm{M})$ of forward primer (27F), $0.3 \mu \mathrm{L}(10 \mu \mathrm{M})$ of reverse primer $(1492 \mathrm{R})$, and $0.75 \mu \mathrm{L}(2.5 \mathrm{U} / \mu \mathrm{L})$ of $T a q$ DNA polymerase. A single 
colony of the isolate $(\mathrm{KJ})$ was picked up with a sterilized toothpick into a PCR reaction tube containing PCR reagents for the amplification of $16 \mathrm{~S}$ rDNA. Amplification of $16 \mathrm{~S}$ rDNA was performed in a thermal cycler (Bio-Rad $\mathrm{T} 100^{\mathrm{TM}}$ ) using an initial denaturation at $94{ }^{\circ} \mathrm{C}$ for $5 \mathrm{~min}$ (one cycle), followed by 35 cycles at $94{ }^{\circ} \mathrm{C}$ for $30 \mathrm{~s}, 55^{\circ} \mathrm{C}$ for $30 \mathrm{~s}$, and $72{ }^{\circ} \mathrm{C}$ for $1 \mathrm{~min}$ and a final extension at $72{ }^{\circ} \mathrm{C}$ for $5 \mathrm{~min}$ (one cycle). In addition, no template control (NTC) reaction without any bacterial colony was used as a negative control. The amplified product was run on a $1.2 \%$ agarose gel along with the marker at a constant voltage and visualized under UV light. The product was stored at $4{ }^{\circ} \mathrm{C}$.

The amplified and purified PCR product was sequenced by SOLGENT, Korea. Partial sequence of $16 \mathrm{~S}$ rDNA of the rhizobacterial isolate was obtained after sequencing. The sequences were compared using BLAST search program for sequence homology of the nucleotides. Closely related sequences were aligned through CLUSTALW using MEGA 6.0 software [23]. The same software was used for the construction of maximum parsimony (MP) tree. Bootstrap replications (1000) were used for the nodes in the phylogenetic tree.

\section{Quantification of ACC deaminase activity}

The bacterial isolate was cultured in DF medium for $20 \mathrm{~h}$ at $28{ }^{\circ} \mathrm{C}$ in a shaker incubator at $200 \mathrm{rpm}$, and $\mathrm{ACC}$ deaminase activity was assayed according to the method of Penrose and Glick [21] with slight modifications. The enzyme ACC deaminase cleaves the substrate ACC to produce $\alpha$-ketobutyrate, which is determined spectrophotometrically at $540 \mathrm{~nm}$ wavelength. The rhizobacterium was inoculated into DF media containing different concentrations $(0,1,2$, and $3 \mathrm{mM})$ of ACC. The amount of $\alpha$ ketobutyrate (nmol) produced was measured by comparing the absorbance of the sample with the values from the standard curve of $\alpha$-ketobutyrate. A stock solution of $\alpha$ ketobutyrate (Sigma Aldrich Co.) was already prepared in Tris- $\mathrm{HCl}(0.1 \mathrm{M}, \mathrm{pH} 8.5)$ and stored at $4{ }^{\circ} \mathrm{C}$.

\section{Plant growth conditions}

White sesame seeds were surface sterilized with $75 \%$ ethanol for $2 \mathrm{~min}$ and thoroughly washed with deionized distilled water to remove any attached debris. The sterilized seeds were sown in pots $(10.0 \times 10.0 \times 8.5 \mathrm{~cm})$ packed with commercially available horticultural soil (Biosento-1, Hungnong-jongmyosa Company, Republic of Korea). These pots were placed in a growth chamber at the laboratory of Biomass and Life Chemistry, Kyungpook National University (KNU), Republic of Korea. Temperature and relative humidity were maintained at $25 \pm 5{ }^{\circ} \mathrm{C}$ and $60 \%$, respectively. Light intensity was maintained at
$650 \mu \mathrm{mol} \mathrm{m} \mathrm{s}^{-2}$ and 16/8 $\mathrm{h}$ light/dark cycle for 4 weeks without bacterial inoculation and waterlogging stress.

\section{Bacterial inoculation and waterlogging treatment}

Bacterial inoculum was prepared by growing ACC deaminase-producing bacteria $(\mathrm{KJ})$ in $\mathrm{LB}$ nutrient broth at $28{ }^{\circ} \mathrm{C}$ for $24 \mathrm{~h}$ in a shaker incubator at $200 \mathrm{rpm}$ until the cells reached their late $\log$ (exponential) phase. To obtain a uniform population of bacterial inoculum $\left(10^{8}\right.$ colonyforming units $[\mathrm{CFU}] / \mathrm{ml}$ ), the optical density of the culture was measured before inoculation. Bacterial culture was centrifuged at $8000 \times g$ for $10 \mathrm{~min}$ at $4{ }^{\circ} \mathrm{C}$. The pellet was washed thrice with distilled water and resuspended in sterile distilled water. The absorbance of the bacterial suspension was adjusted $\left(A_{600 \mathrm{~nm}}=1.0\right)$ before its inoculation in $50 \mathrm{~mL}$ of suspension (just once during the experiment) of sesame plants grown under growth chamber. The inoculation process was carried out 1 week prior to the application of waterlogging stress. For control, only distilled water $(50 \mathrm{~mL})$ was applied to the seedlings. The seedlings were subsequently subjected to waterlogging stress by placing the pots under submerged conditions in a water tank. Water level was maintained up to the surface of the soil. A total of 10 days of waterlogging was applied to the seedlings. On the other hand, a set of seedlings was grown in the original growth condition without water stress (control).

\section{Measurement of growth parameters}

After 10 days of waterlogging stress, the different growth variables, including, height $(\mathrm{cm})$, root length $(\mathrm{cm})$, and fresh and dry biomass $(\mathrm{g})$, were measured. The seedlings were weighed immediately after harvesting to obtain fresh biomass, while dry biomass was measured after oven drying at $70{ }^{\circ} \mathrm{C}$ overnight.

\section{Chlorophyll content}

The concentration of chlorophyll was measured at different time points (0-day post-flooding [0-DPF], 2-DPF, 4-DPF, and 8-DPF) from the commencement of waterlogging treatment to just before the end of the experiment. For accurate and easy determination of chlorophyll content, CCM-300 (Opti-Sciences) chlorophyll content meter was used. The working principal and design of CCM-300 is based on the work of Gitelson [24] using the ratio of fluorescence at $735 / 700 \mathrm{~nm}$ to determine chlorophyll content. The results were deciphered as relative chlorophyll content in $\mathrm{mg} / \mathrm{m}^{2}$. The chlorophyll content of the same seedling in each treatment was measured in triplicate using the third and fourth most recent and fully expanded leaf. 


\section{Photosynthesis analysis}

Photosynthesis yield analyzer (Mini-PAM, Effeltrich, Germany) was used to calculate the electron transport rate (ETR) resulting from the rapid light curve (RLC) measurements. Photosynthesis analysis of leaves from each treatment was recorded at room temperature. The leaf clip holder (Walz, Effeltrich, Germany, 2030-B) was connected to the photosynthesis yield analyzer, which was also connected to a computer with data acquisition software (Walz, DA-2000). All required measurements were taken with the saturation pulse method according to the manual of MiniPAM. Mini-PAM accounts for all applicable fluorescence parameters as well as actinic irradiance and leaf temperature and estimates ETR. Parameters such as ETR and photosynthetically active radiation (PAR) were calculated for the third and fourth leaf (lamina region) of the plant. ETR was calculated as follows:

$\mathrm{ETR}=$ Yield $\times \mathrm{PAR} \times 0.5 \times \mathrm{AF}$

where yield shows the whole amount of photochemical quantum $\left(Y=\left[\mathrm{F}^{\prime} \mathrm{m}-\mathrm{F}^{\prime}\right] / \mathrm{F}^{\prime} \mathrm{m}\right), 0.5$ is the constant of photon energy absorbed by photosystems (I and II) during sampling under in situ condition, and AF is the constant (estimated as 0.84) that represents the absorption factor of thallus. Three measurements were taken per pot and two pots per treatment, while the total number of treatments was four

\section{Data analysis}

The study included four treatments, and each treatment had three replicates in a completely randomized design. Treatment effects were determined with the analysis of variance followed by $t$ test at a probability level of $P=0.05$.

\section{Results}

\section{Bacterial identification and screening for the utilization of the substrate ACC}

The rhizobacterial isolate obtained from the melon field in Seongju, Republic of Korea, was subjected to possible identification based on the Bergey's Manual of Determinative Bacteriology [19]. The strain was identified as a gram-negative, short rod-shaped bacterium with circular colonies. The isolate also presented positive results for both oxidase and catalase tests. In addition, the isolate was tested for substrate ACC utilization on DF minimal medium supplemented with the substrate ACC or $\left(\mathrm{NH}_{4}\right)_{2} \mathrm{SO}_{4}$, and appropriate bacterial growth was recorded on
$\left(\mathrm{NH}_{4}\right)_{2} \mathrm{SO}_{4}$-containing plates and ACC (3 mM)-supplemented plates after 5 days of incubation at $28{ }^{\circ} \mathrm{C}$ (Fig. 1). The bacterial growth on ACC-supplemented plates revealed the phenotypic identification of $a c d S$ gene that encodes for ACC deaminase, which utilizes the substrate ACC as a sole source of nitrogen.

The rhizobacterial isolate Pseudomonas KJ was evaluated with molecular methods for its precise identification. Molecular characterization based on 16S rDNA sequencing of the partial sequence (1501 bp) of the isolate Pseudomonas KJ was compared with that from the database by BLAST (https://blast.ncbi.nlm.nih.gov/Blast.cgi). The sequences from direct amplification of 16S rDNA and MP analysis revealed that the strain was closely related to Pseudomonas veronii, while BLASTn search showed $99 \%$ homology (Fig. 2). Thus, the rhizobacterium Pseudomonas $\mathrm{KJ}$ was characterized on the basis of sequencing (sequences not shown here) of $16 \mathrm{~S}$ rDNA amplicon and confirmed as a strain of $P$. veronii $\mathrm{KJ}$ represented in the phylogenetic tree (Fig. 2).

\section{Amplification and sequencing of acdS gene and ACC deaminase activity determination}

After confirming the phenotypic identification of $\operatorname{acdS}$ gene on minimal medium, specific primers were designed for the amplification of acdS gene of the rhizobacterium $P$. veronii KJ. The identified strain yielded a 1001 bp DNA fragment (sequence not shown) and gene sequencing and BLASTn search analysis confirmed the presence of $a c d S$ gene in $P$. veronii $\mathrm{KJ}$. Different concentrations of ACC were used for the quantification of ACC deaminase activity of $P$. veronii KJ. Higher level of $\left(979 \mu \mathrm{M} \mathrm{h}^{-1} \mathrm{mg}^{-1}\right)$ of $\alpha$-ketobutyrate was measured at higher concentration ( $3 \mathrm{mM}$ ) of ACC in the growth media, while the level of $\alpha$-ketobutyrate produced gradually decreased with a decrease in the concentration of ACC (Fig. 3). Together these data indicate the presence and expression of ACC deaminase in $P$. veronii $\mathrm{KJ}$.

\section{Effect on sesame growth and biomass}

The screening results presented in Fig. 4 and Table 1 show that the application of ACC deaminase-producing $P$. veronii $\mathrm{KJ}$ resulted in a significant decrease $(P \leq 0.05)$ in waterlogging stress-associated damage in sesame seedlings. The root length, shoot length, fresh biomass, and dry biomass significantly increased following treatment with $P$. veronii $\mathrm{KJ}$ under waterlogging stress condition (Table 1). The advantages of bioinoculation on the growth of sesame seedlings were observed in the pot experiment, wherein the seedlings demonstrated the potential role of ACC deaminase-producing $P$. veronii $\mathrm{KJ}$ under waterlogged condition (Fig. 4). 


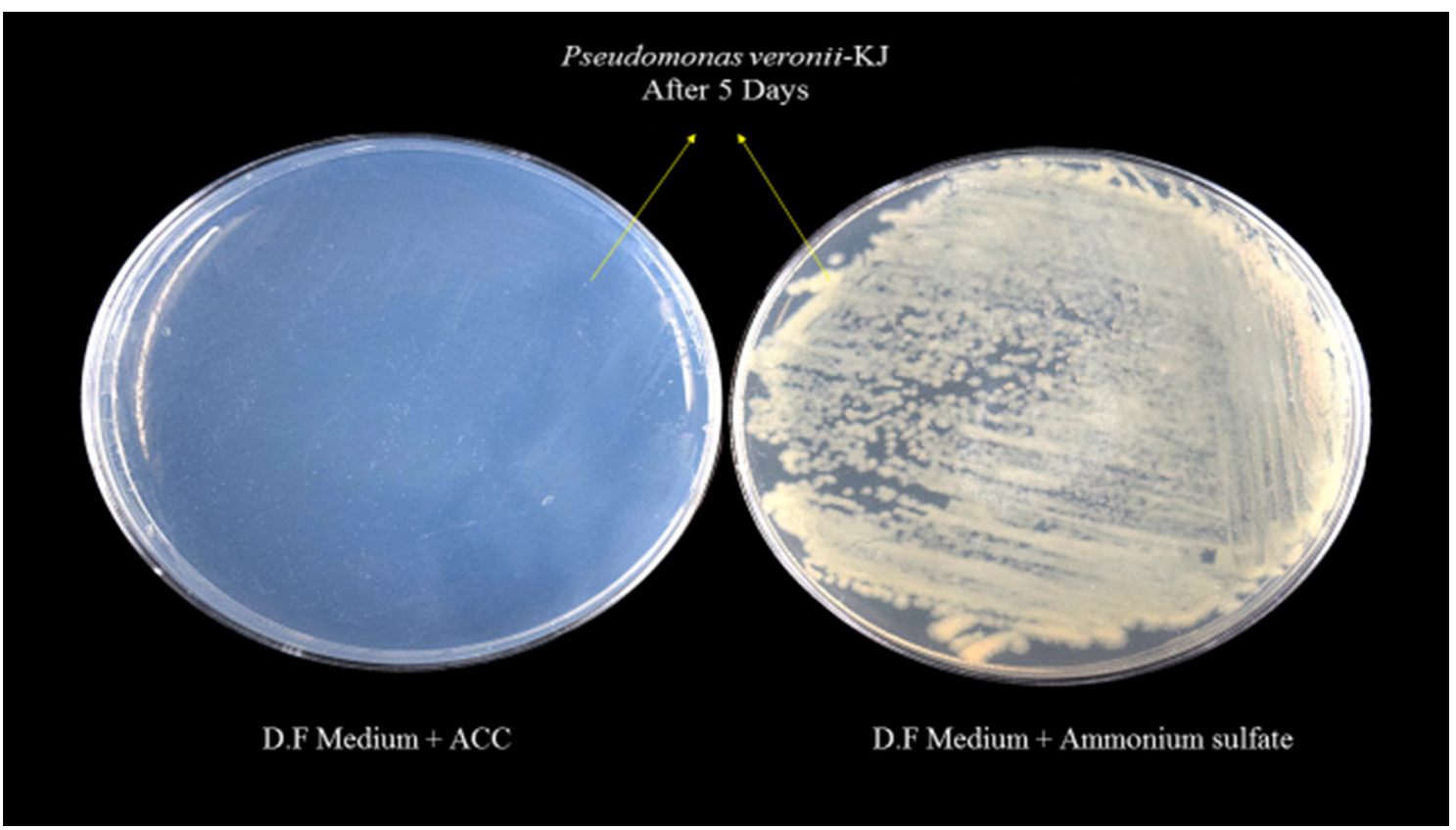

Fig. 1 Screening of Pseudomonas KJ for the utilization of ACC on DF medium. The minimal medium plates were supplemented with ACC $(3 \mathrm{mM})$ or ammonium sulfate $(2 \mathrm{~g} / \mathrm{L})$. Bacterial growth was recorded on both ammonium sulfate-containing and ACC-supplemented plates after 5 days of incubation at $28{ }^{\circ} \mathrm{C}$

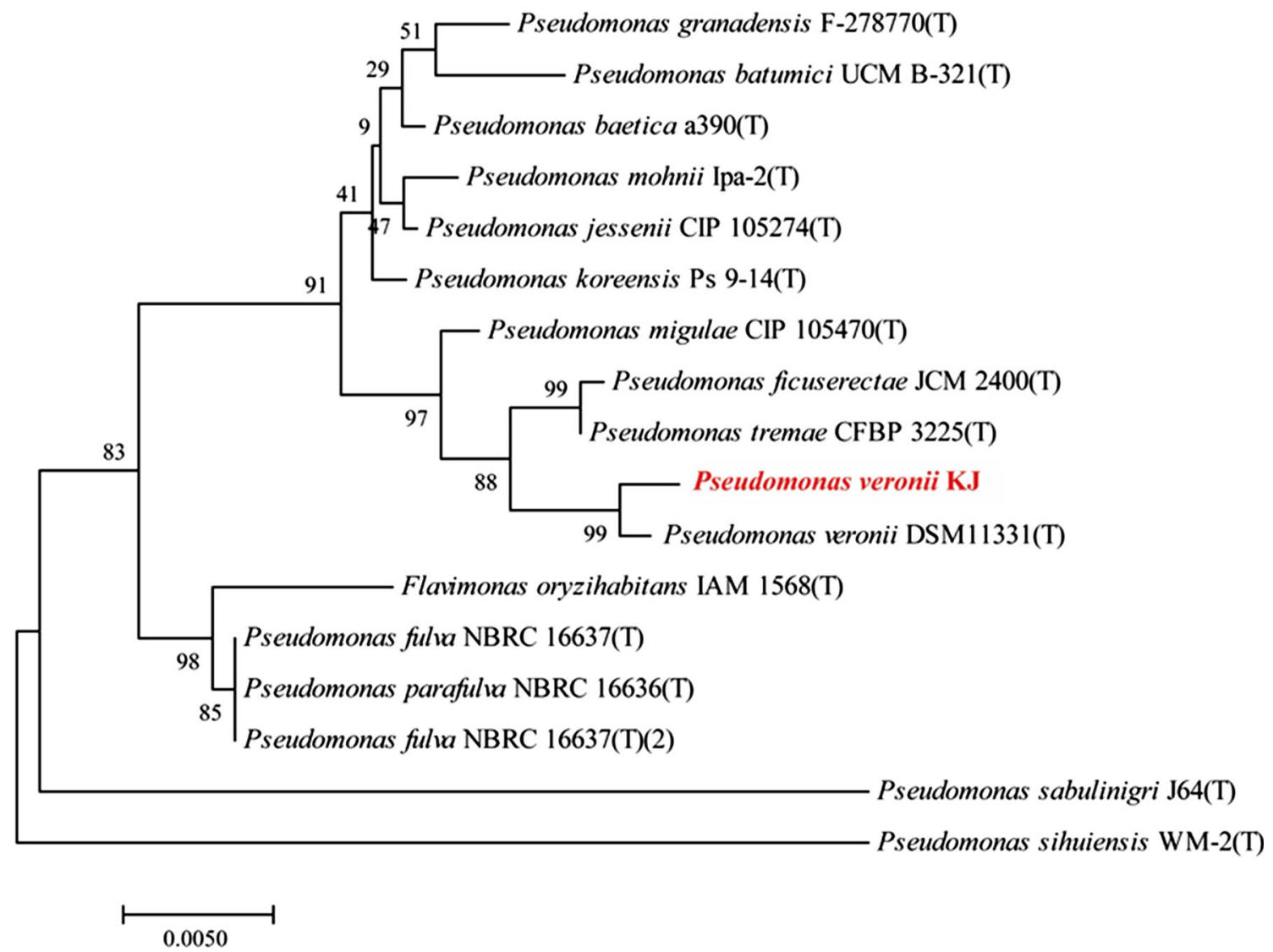

Fig. 2 Phylogenetic analysis of $P$. veronii KJ using 16S rDNA partial sequences. The genetic relatedness between $P$. veronii $\mathrm{KJ}$ and other members of Pseudomonas species was analyzed using MEGA 6.0 software, and the same software was used for the construction of maximum parsimony tree. The nodal robustness of the tree was assessed using 1000 bootstrap replicates 


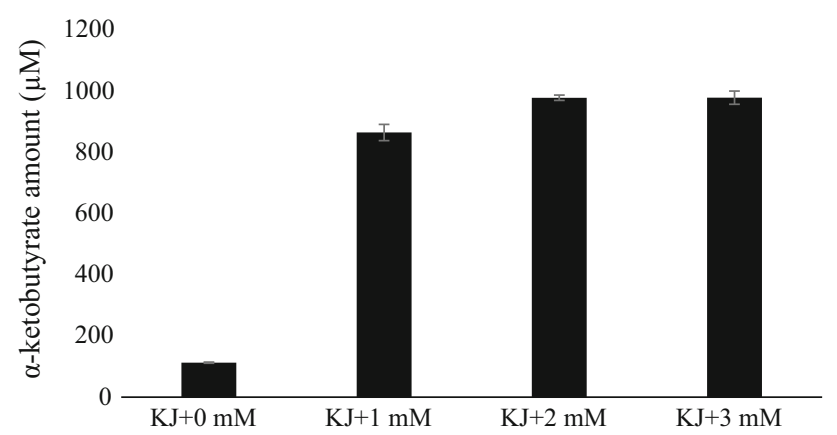

Fig. 3 ACC deaminase activity of $P$. veronii $\mathrm{KJ}$ in $\mathrm{DF}$ minimal medium supplemented with different concentrations $(0,1,2$, and $3 \mathrm{mM}$ ) of the substrate ACC. The amount of $\alpha$-ketobutyrate $(\mu \mathrm{M})$ produced was directly proportional to the concentration of ACC in the media

The prominent adverse effect of waterlogging stress was observed on the shoot length of sesame plant that decreased by about $41 \%$ as compared to unstressed control plants. However, ACC deaminase-producing bacteria significantly $(P \leq 0.05)$ improved the shoot length of plants under waterlogged condition, as observed from up to $21 \%$ increase in the length of treated plants as compared with that of untreated plants in waterlogged condition. Although bacteria-treated plants in the absence of waterlogging stress showed improved shoot length as compared with unstressed control plants, the difference was insignificant (Table 1). Vigorous growth of adventitious roots was observed in bacteria-treated plants, highlighting the capa- bility of sesame plants to survive under waterlogging condition. Furthermore, substantial difference was recorded between the root length of control and stressed plants; plants treated with bacteria showed robust growth and noticeable increase in root length as compared with stressed plants. The root length of plants in waterlogged condition was significantly reduced $(P \leq 0.05)$ by $51.6 \%$ as compared with the root length of control plants. On the contrary, plants treated with $P$. veronii $\mathrm{KJ}$ under waterlogging condition showed $28.93 \%$ increase in the root length as compared with untreated flooded plants. $P$. veronii $\mathrm{KJ}$ significantly increased the fresh and dry biomass of plants under flooding conditions. Hence, ACC deaminaseproducing $P$. veronii $\mathrm{KJ}$ showed prominent results by mitigating the flooding stress-associated damages in sesame plants (Table 1).

\section{Chlorophyll content}

Waterlogging condition greatly affects the chlorophyll content of leaves, while the bacteria (producing ACC deaminase) residing in the near vicinity of plant roots may alleviate the damage caused by flooding stress [18]. In our results, the chlorophyll content of the leaves was significantly $(P \leq 0.05)$ affected by flooding stress. In comparison with control plants, waterlogged plants showed a prominent reduction in their chlorophyll content. On the other hand, plants treated with $P$. veronii $\mathrm{KJ}$ and subjected to waterlogged condition showed a significant $(P \leq 0.05)$

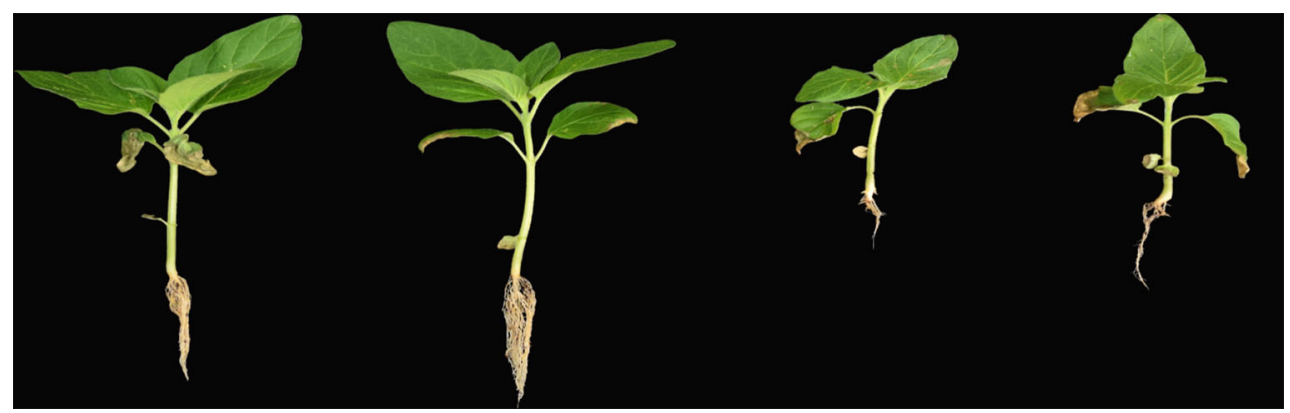

Fig. 4 Morphological comparison of S. indicum plants

Table 1 Effect of waterlogging stress on $S$. indicum treated with P. veronii $\mathrm{KJ}$

\begin{tabular}{llccc}
\hline Treatment & S.L. $(\mathrm{cm})$ & R.L. $(\mathrm{cm})$ & F.B. $(\mathrm{g})$ & D.B. $(\mathrm{g})$ \\
\hline Control & $24.5 \pm 0.60^{\mathrm{a}}$ & $9.1 \pm 1.04^{\mathrm{a}}$ & $9.22 \pm 2.24^{\mathrm{a}}$ & $3.15 \pm 0.82^{\mathrm{a}}$ \\
Bacterized & $25.5 \pm 0.28^{\mathrm{a}}$ & $15.6 \pm 4.4^{\mathrm{b}}$ & $14.18 \pm 1.6^{\mathrm{b}}$ & $5.31 \pm 0.87^{\mathrm{b}}$ \\
Flooded & $14.6 \pm 2.32^{\mathrm{b}}$ & $4.4 \pm 0.51^{\mathrm{c}}$ & $3.54 \pm 0.23^{\mathrm{c}}$ & $0.55 \pm 0.15^{\mathrm{c}}$ \\
Flooded + bacterized & $17.8 \pm 1.75^{\mathrm{c}}$ & $7.03 \pm 0.85^{\mathrm{d}}$ & $4.00 \pm 0.47^{\mathrm{d}}$ & $0.82 \pm 0.08^{\mathrm{d}}$ \\
\hline
\end{tabular}

The values in each column represent the mean \pm SD

S.L., shoot length; R.L., root length; F.B., fresh biomass; D.B., dry biomass

Those marked with different letters in each column are significantly different at $P \leq 0.05$, as analyzed by $t$ test 


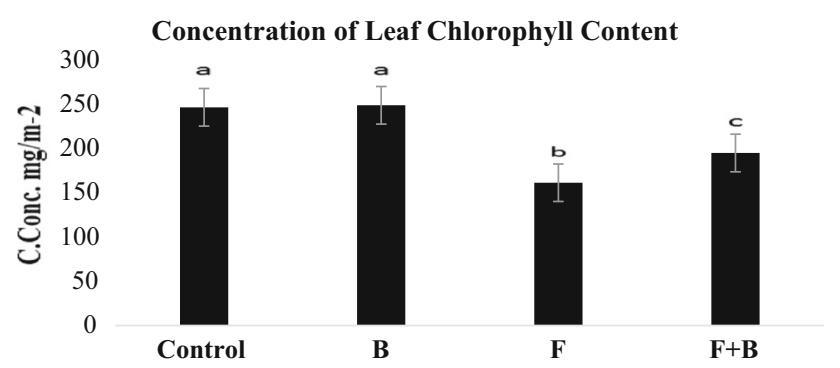

Fig. 5 Effect of flooding stress on the chlorophyll content of $S$. indicum $\mathrm{L}$. leaves upon treatment with ACC deaminase-producing $P$. veronii $\mathrm{KJ}$. The chlorophyll content significantly reduced in flooded plants $(F)$ as compared with control. However, plants treated with bacteria showed a significant increase in their chlorophyll content after flooding $(F+B)$ stress as compared with stressed plants without bacterial treatment. The unstressed bacteria-treated plants $(B)$ and control plants showed no significant difference in their chlorophyll content. Values are presented as mean \pm SD (error bars). Different letters over error bars indicate significant differences $(P \leq 0.05)$ using $t$ test

increase in their chlorophyll content as compared with nontreated plants. Upon induction of flooding stress, a minor increase was observed in the chlorophyll content of flooded plants that dramatically declined thereafter, with more than $30 \%$ decrease in the chlorophyll content reported (Fig. 5).

The chlorophyll fluorescence ratio (CFR) was initially more than 0.94 and gradually reduced (0.78-0.94) under flooding condition. CFR of plants from the control group was more than 0.94 until the end of the experiment. Bacteria-treated plants showed higher chlorophyll content and CFR value as compared with the control plants, but no significant $(P \leq 0.05)$ difference was noted. On the contrary, plants subjected to flooding stress presented a very low CFR (0.78) value at the end of the experiment as compared to those treated with $P$. veronii $\mathrm{KJ}$ in waterlogged condition (Fig. 6).

The content of chlorophyll decreased in waterlogged plants as compared with unstressed plants. On the other hand, waterlogged plants treated with $P$. veronii $\mathrm{KJ}$ showed significantly higher chlorophyll level and leaf CFR value at $735 / 700 \mathrm{~nm}$. Hence, ACC deaminase-producing P. veronii $\mathrm{KJ}$ mitigates the damage induced by flooding stress on the chlorophyll content and contributes to the growth and development of plants.

\section{Fluorescence yield and RLC}

The photosynthetic characteristics of plant leaves were associated with the decrease in the chlorophyll content under waterlogged condition. The ETR value of PS-II presented a negative deviation at the end of experiment (Table 2). Figure 7 and Table 2 show the aptitude of RLC and fluorescence yield, respectively, for sesame leaves under waterlogged condition.

The reducing performance of ETR was more obvious for flooded plants than the control, while plants treated with bacteria under flooded condition showed a minimal decrease in ETR, thereby expressing a reasonable tolerance for waterlogging stress. The decrease in ETR may serve as an indicator of electron transport chain deterioration in PSII. The photochemical process is more sensitive in sesame plant subjected to flooding stress than that exposed to bacterial treatment, which enables the plant to maintain relatively normal values of ETR under waterlogged condition. All other photosynthetic characteristics were greatly affected in response to flooding stress. Flooded plants showed a very low Fm value as compared with unstressed plants, which showed reduced efficiency of heat dissipation

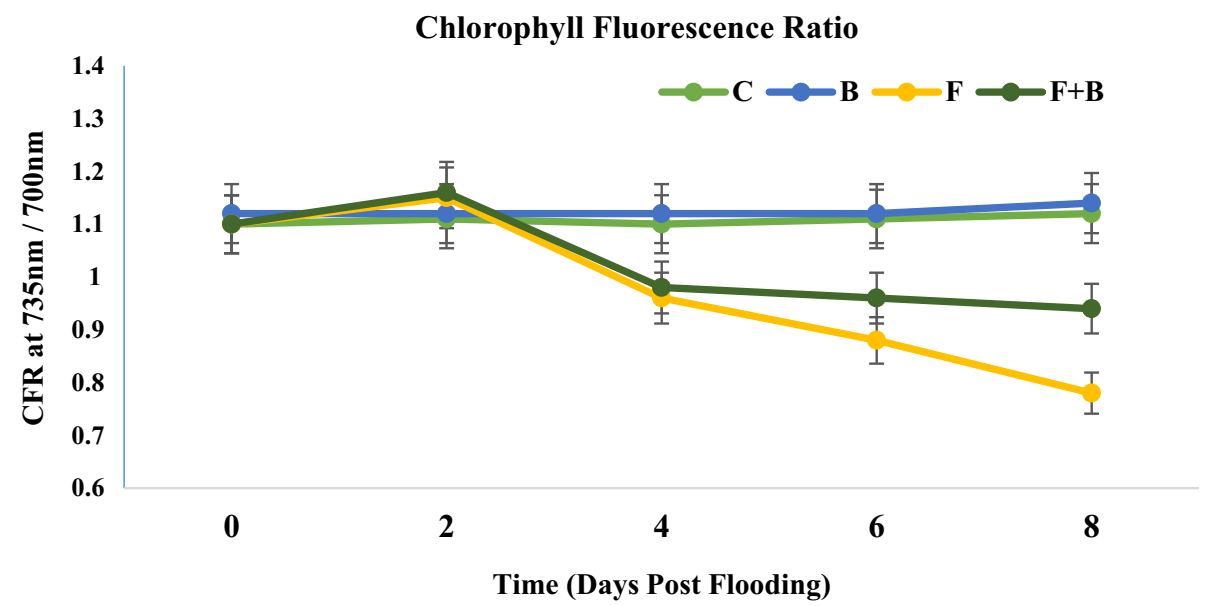

Fig. 6 Effect of flooding stress on the leaf chlorophyll fluorescence ratio at $735 / 700 \mathrm{~nm}$. S. indicum in flooding $(F)$ stress condition showed significantly lower CFR value than in control conditions $(C)$. However, the non-stressed bacteria-treated plants $(B)$ and control plants $(C)$ showed no significant difference in CFR value. ACC deaminase-producing bacteria significantly increase the CFR value under flooded condition $(F+B)$ at different time points. Values are presented as mean $\pm \mathrm{SD}$ (error bars) 
Table 2 Different parameters of chlorophyll fluorescence after 8 days of flooding stress

\begin{tabular}{|c|c|c|c|c|c|c|}
\hline Treatment & $\mathrm{Y}(\mathrm{II})$ & ETR & ETRm & Fo & $F m^{\prime}$ & $F m$ \\
\hline Control & $0.804 \pm 0.005^{\mathrm{a}}$ & $68.7 \pm 10^{\mathrm{a}}$ & $86.12 \pm 3^{\mathrm{a}}$ & $616.3 \pm 39^{\mathrm{a}}$ & $1990 \pm 86^{\mathrm{a}}$ & $3684 \pm 258^{\mathrm{a}}$ \\
\hline Bacterized & $0.806 \pm 0.002^{\mathrm{a}}$ & $69.7 \pm 7^{\mathrm{a}}$ & $84.3 \pm 2^{\mathrm{a}}$ & $661.3 \pm 7^{\mathrm{a}}$ & $1858 \pm 76^{\mathrm{a}}$ & $3674 \pm 42^{\mathrm{a}}$ \\
\hline Flooded & $0.735 \pm 0.009^{\mathrm{b}}$ & $23.9 \pm 1^{b}$ & $52.8 \pm 4^{\mathrm{b}}$ & $752.3 \pm 18^{b}$ & $1468 \pm 82^{\mathrm{b}}$ & $2318 \pm 96^{\mathrm{b}}$ \\
\hline Flooded + bacterized & $0.770 \pm 0.002^{\mathrm{c}}$ & $38.1 \pm 4^{\mathrm{c}}$ & $57.5 \pm 3^{c}$ & $711.6 \pm 3^{c}$ & $1704 \pm 26^{\mathrm{c}}$ & $3264 \pm 56^{\mathrm{a}}$ \\
\hline
\end{tabular}

Values in each column represent the mean \pm SEM and those marked with different letters in each column are significantly different at $P \leq 0.05$, as analyzed by $t$ test

Fig. 7 ETR as a function of actinic irradiance. Rapid light curves of control $(C)$, flooded $(F)$, bacteria-treated $(B)$ and flooded + bacteria-treated $(F+B) S$. indicum plant. Mean ETR are plotted with irradiance $\left(\mu \mathrm{mol} \mathrm{m} \mathrm{m}^{-2} \mathrm{~s}^{-1}\right)$

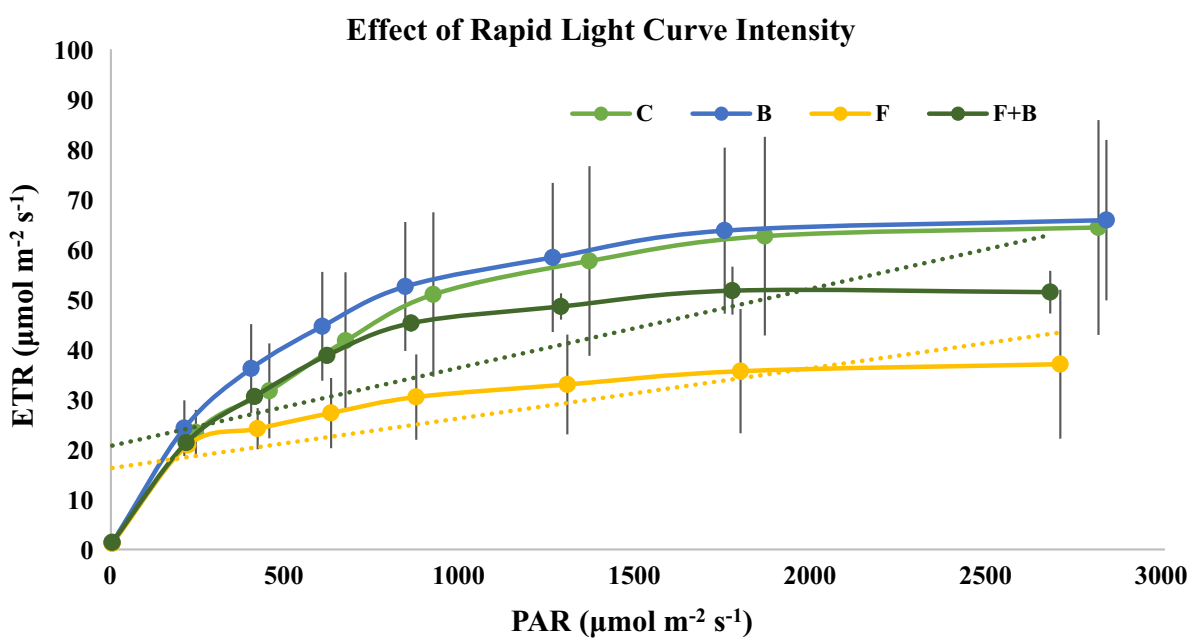

in waterlogged condition. The increase in Fo value revealed the stress on plants and is also known as "increased minimal fluorescence." The variation in the quantum yield of PS-II (Y-II) and maximum relative electron transport rate $(\mathrm{ETRm})$ values manifested the adverse effect of flooding stress on sesame plant (Table 2).

In general, the results of $F v / F m$ are used to describe the effects of environmental stress conditions. At day 0 following flooding, $F v / F m$ values for all treatment groups were more than 0.8 , while a small fluctuation was observed on the second day of waterlogged condition. The unstressed control and bacteria-treated plants presented maximum $F v / F m$ values until the experiment end. However, flooded plants showed a significant decrease in $F v / F m$ value after day 4 of flooding. On the other hand, flooded plants treated with ACC deaminase-producing $P$. veronii $\mathrm{KJ}$ exhibited a significant increase in $F v / F m$ value as compared with untreated waterlogged plants (Fig. 8). These results indicate that ACC deaminase-producing bacteria contribute to the photochemical process of plants in flooding stress condition.

The results for $F v / F m$ were measured every second day throughout the experiment and allowed us to appropriately investigate the changes over time and across different treatment conditions. The standard value $(0.83)$ of $F v / F m$ was determined by Bjoerkman and Demmig [25], while the control plants in our experiments showed close approximation to the standard value throughout the experiment. However, $F v / F m$ value for flooded sesame plants gradually declined after day 4 and reached 0.73 on day 8 of the experiment. On the other hand, plants treated with $P$. veronii $\mathrm{KJ}$ showed higher values for $F v / F m$ until the experiment end (Fig. 8).

\section{Discussion}

Several ACC deaminase-producing bacteria have been known to promote plant growth and mitigate the effects of different environmental stresses, including waterlogging stress [18, 26, 27]. The study of Honma and Shimomura [13] showed the deamination of 1-aminocyclopropane-1carboxylate (ACPC) as a sole nitrogen source by bacterial (Pseudomonas spp.) ACC deaminase. Later, Glick et al. [28] suggested a model for the amelioration of abiotic stress damage caused by ACC deaminase-producing rhizobacteria. The study of $\mathrm{Li}$ et al. [29] concluded the presence of acdS gene for the synthesis of ACC deaminase 
Fig. 8 The effect of flooding on actual quantum efficiency of PS-II. $F v / F m$ of control $(C)$, flooded $(F)$, bacteria-treated $(B)$, and flooded + bacteria-treated $(F+B) S$. indicum at different time points. Mean $F v / F m$ values are plotted with time (postflooding days)
Effect of Flooding stress on Actual Quantum Efficiency of PS-II

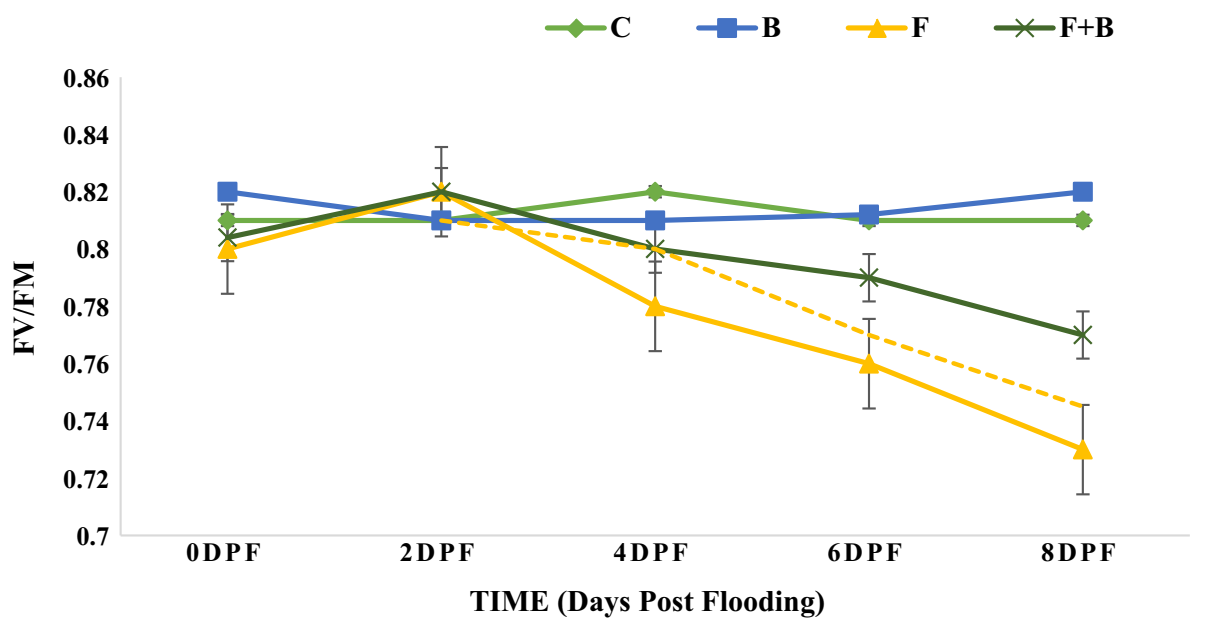

and promotion of canola root elongation. In the present study, the phenotypic identification of $a c d S$ gene in the rhizobacterium $P$. veronii $\mathrm{KJ}$ paved the way for $16 \mathrm{~S}$ rDNA sequencing, amplification, and sequencing of acdS gene, and quantification of ACC deaminase activity. Moreover, the alleviation of flooding stress-associated damage after bacterial treatment was confirmed through the changes in different growth-related variables such as root length, shoot length, fresh and dry biomass, concentration of chlorophyll, and chlorophyll fluorescence.

Pseudomonas spp. have been reported to produce ACC deaminase and reduce flooding stress-associated damage in crop plants [30-32]. We evaluated the ability to utilize ACC in DF minimal medium for the phenotypic identification of acdS gene (Fig. 1) and found that the test strain showed robust growth on DF minimal medium supplemented with the substrate ACC. This observation is consistent with the results of [32], wherein Pseudomonas isolate CPA123 was shown to produce ACC deaminase and utilize ACC as the sole nitrogen source on DF minimal media.

Drancourt et al. [33] confirmed Pseudomonas, Agrobacterium, and Phyllobacterium on the basis of $16 \mathrm{~S}$ rDNA sequences. In agreement with this study, the direct amplification and sequencing of 16S rDNA sequences of $P$. veronii $\mathrm{KJ}$ revealed $99 \%$ homology to those of known Pseudomonas species (Fig. 2). According to Glick et al. [34] the mutants of $P$. putida lacking genes for ACC deaminase were unable to promote growth of canola seedlings. In our study, the precise confirmation of acdS gene in the characterized strain $(P$. veronii $\mathrm{KJ})$ favored its use as a bioinoculant in waterlogged condition.

Prolonged water stress adversely affects different aspects of plant physiology, leading to a substantial decrease in the yield of crop plants, with the exception of rice $[15,35,36]$. In the present study, sesame plants were treated with ACC deaminase-producing $P$. veronii $\mathrm{KJ}$ and showed a significantly higher tolerance to waterlogging stress as compared with untreated flooded plants. In comparison with untreated stressed plants, flooded plants treated with ACC deaminase-producing bacteria showed a significant difference in root length, shoot length, fresh biomass, dry biomass, and chlorophyll content (Table 1, Fig. 5). This result is in line with that reported by Grichko and Glick [18]. These authors reported that the shoot height and fresh and dry shoot weight of tomato plants reduced after 9 days of flooding and that plants treated with ACC deaminase-producing bacteria showed significantly higher tolerance to flooding stress condition. It was suggested that the protection against flooding stress resulted in significant differences in the overall plant growth and leaf chlorophyll content. Recently, the study of Forghani et al. [37] revealed that upon initiation of stress condition the leaves of sweet sorghum increase the amount of total chlorophyll and carotenoid contents. Similarly, in our study, sesame plants initially showed a minor increase in the concentration of chlorophyll, which declined dramatically thereafter and more than $30 \%$ decrease was recorded in the chlorophyll content of waterlogged plants. On the contrary, plants treated with $\mathrm{ACC}$ deaminase-producing $P$. veronii $\mathrm{KJ}$ presented a significant increase in their chlorophyll content (Fig. 5). Grichko and Glick [18] also showed that leaf chlorophyll content decreased in flooded plants as compared with control plants and that the concentration of chlorophyll was significantly higher in flooded plants treated with ACC deaminase-producing bacteria as compared with untreated waterlogged plants. Thus, waterlogging stress may have a significant impact on plant photosynthesis and often leads to low photochemical efficiency in leaves [15]. In the present study, ETR of PS-II displayed a negative deviation after 8 days of waterlogging, and the reduced performance of ETR was more 
obvious for the waterlogged plants than the control plants. On the other hand, bacteria-treated plants under waterlogged condition showed a minimum decrease in ETR value as compared to untreated plants, thereby highlighting their tolerance to waterlogging stress (Table 2). The decrease in ETR may serve as an indicator of electron transport chain deterioration in PS-II. This observation is consistent with the report of Smethurst and Shabala [15], wherein the adverse effect of waterlogging stress on photochemical process is revealed. Overall, our results indicate that waterlogged condition adversely affects different physiological aspects of sesame plant, while treatment with ACC deaminase-producing $P$. veronii $\mathrm{KJ}$ results in the alleviation of the damage and contributes to plant growth and development.

Acknowledgments This work was carried out with the support of Cooperative Research Program for Agriculture Science \& Technology Development (Project No. PJ012286042018) Rural Development Administration, Republic of Korea.

\section{References}

1. Wei W, Li D, Wang L, Ding X, Zhang Y, Gao Y, Zhang X (2013) Morpho-anatomical and physiological responses to waterlogging of sesame (Sesamum indicum L.). Plant Sci 208:102-111

2. Couch A, Gloaguen RM, Langham DR, Hochmuth GJ, Bennett JM, Rowland DL (2017) Non-dehiscent sesame (Sesamum indicum L.): its unique production potential and expansion into the southeastern USA. Journal of Crop Improvement 31(2):101-172

3. Martinchik AN (2011) Nutritional value of sesame seeds. Vopr Pitan 80(3):41-43

4. Lakhanpaul S, Singh V, Kumar S, Bhardwaj D, Bhat KV (2012) Sesame: overcoming the abiotic stresses in the queen of oilseed crops. Improv Crop Resist Abiotic Stress 1(2):1251-1283

5. Ullah I, Waqas M, Khan MA, Lee IJ, Kim WC (2017) Exogenous ascorbic acid mitigates flood stress damages of Vigna angularis. Appl Biol Chem 60(6):603-614

6. Glick BR (2014) Bacteria with ACC deaminase can promote plant growth and help to feed the world. Microbiol Res 169(1):30-39

7. Morales-Olmedo M, Ortiz M, Selles G (2015) Effects of transient soil waterlogging and its importance for rootstock selection. Chil J Agric Res 75:45-56

8. Glick BR, Todorovic B, Czarny J, Cheng Z, Duan J, McConkey B (2007) Promotion of plant growth by bacterial ACC deaminase. Crit Rev Plant Sci 26(5-6):227-242

9. Lee CH, Seo SH, Kwon OJ, Park M, Kim WC, Kang SJ (2016) Functional characterization of a chemical defoliant that activates fruit cluster Leaf defoliation in 'Fuji' apple trees. Appl Biol Chem 59(5):711-720

10. Sasidharan R, Hartman S, Liu Z, Martopawiro S, Sajeev N, Van Veen H, Voesenek LA (2018) Signal dynamics and interactions during flooding stress. Plant Physiol 176(2):1106-1117

11. Singh RP, Shelke GM, Kumar A, Jha PN (2015) Biochemistry and genetics of ACC deaminase: a weapon to "stress ethylene" produced in plants. Front Microbiol 6:937

12. Glick BR (2012) Plant growth-promoting bacteria: mechanisms and applications. Scientifica. https://doi.org/10.6064/2012/ 963401
13. Honma M, Shimomura T (1978) Metabolism of 1-aminocyclopropane-1-carboxylic acid. Agric Biol Chem 43:1825-1831

14. Kalaji HM, Jajoo A, Oukarroum A, Brestic M, Zivcak M, Samborska IA, Ladle RJ (2016) Chlorophyll a fluorescence as a tool to monitor physiological status of plants under abiotic stress conditions. Acta Physiol Plant 38(4):102

15. Smethurst CF, Shabala S (2003) Screening methods for waterlogging tolerance in lucerne: comparative analysis of waterlogging effects on chlorophyll fluorescence, photosynthesis, biomass and chlorophyll content. Funct Plant Biol 30(3):335-343

16. Justin SHFW, Armstrong W (1987) The anatomical characteristics of roots and plant response to soil flooding. New Phytol 106(3):465-495

17. Valentini R, Epron D, Angelis PD, Matteucci G, Dreyer E (1995) In situ estimation of net $\mathrm{CO}_{2}$ assimilation, photosynthetic electron flow and photorespiration in Turkey oak $(Q$. cerris L.) leaves: diurnal cycles under different levels of water supply. Plant Cell Environ 18(6):631-640

18. Grichko VP, Glick BR (2001) Amelioration of flooding stress by ACC deaminase-containingplant growth-promoting bacteria. Plant Physiol Biochem 39(1):11-17

19. Buchanan E, Gibbons NE, Stewart WDP (1994) Bergeys manual of determinative bacteriology (edited by R. Solar Energy) 24: 607-616

20. Dworkin M, Foster JW (1958) Experiments with some microorganisms which utilize ethane and hydrogen. J Bacteriol 75:592-601

21. Penrose DM, Glick BR (2003) Methods for isolating and characterizing ACC deaminase containing plant growth promoting rhizobacteria. Physiol Plant 118(1):10-15

22. Giovannoni SJTB, Britschgi CL, Moyer Field KG (1990) Genetic diversity in Sargasso Sea bacterioplankton. Nature 345:60-63

23. Tamura K, Stecher G, Peterson D, Filipski A, Kumar S (2013) MEGA6: molecular evolutionary genetics analysis version 6.0. Mol Biol Evol 30(12):2725-2729

24. Gitelson AA, Buschmann C, Lichtenthaler HK (1999) The chlorophyll fluorescence ratio F735/F700 as an accurate measure of the chlorophyll content in plants. Remote Sens Environ 69(3):296-302

25. Björkman O, Demmig B (1987) Photon yield of $\mathrm{O}_{2}$ evolution and chlorophyll fluorescence characteristics at $77 \mathrm{~K}$ among vascular plants of diverse origins. Planta 170(4):489-504

26. Farwell AJ, Vesely S, Nero V, Rodriguez H, McCormack K, Shah S, Glick BR (2007) Tolerance of transgenic canola plants (Brassica napus) amended with plant growth-promoting bacteria to flooding stress at a metal-contaminated field site. Environ Pollut 147(3):540-545

27. Nascimento F, Brígido C, Alho L, Glick BR, Oliveira S (2012) Enhanced chickpea growth-promotion ability of a Mesorhizobium strain expressing an exogenous ACC deaminase gene. Plant Soil 353(1-2):221-230

28. Glick BR, Penrose DM, Li J (1998) A model for the lowering of plant ethylene concentrations by plant growth-promoting bacteria. J Theor Biol 190(1):63-68

29. Li J, Ovakim DH, Charles TC, Glick BR (2000) An ACC deaminase minus mutant of Enterobacter cloacae UW4No longer promotes root elongation. Curr Microbiol 41(2):101-105

30. Hall JA, Peirson D, Ghosh S, Glick BR (1996) Root elongation in various agronomic crops by the plant growth promoting rhizobacterium Pseudomonas putida GR12-2. Isr J Plant Sci 44(1):37-42

31. Shaharoona B, Arshad M, Zahir ZA, Khalid A (2006) Performance of Pseudomonas spp. containing ACC-deaminase for improving growth and yield of maize (Zea mays L.) in the presence of nitrogenous fertilizer. Soil Biol Biochem 38(9):2971-2975 
32. Khandelwal A, Sindhu SS (2013) ACC deaminase containing rhizobacteria enhance nodulation and plant growth in Clusterbean (Cyamopsis tetragonoloba L.). J Microbiol Res 3(3):117-123

33. Drancourt M, Bollet C, Carlioz A, Martelin R, Gayral JP, Raoult D (2000) 16S ribosomal DNA sequence analysis of a large collection of environmental and clinical unidentifiable bacterial isolates. J Clin Microbiol 38(10):3623-3630

34. Glick BR, Jacobson CB, Schwarze MM, Pasternak JJ (1994) 1-Aminocyclopropane-1-carboxylic acid deaminase mutants of the plant growth promoting rhizobacterium Pseudomonas putida GR12-2 do not stimulate canola root elongation. Can J Microbiol 40(11):911-915
35. Castonguay Y, Nadeau P, Simard RR (1993) Effects of flooding on carbohydrate and $\mathrm{ABA}$ levels in roots and shoots of alfalfa. Plant, Cell Environ 16:695-702

36. Rogers ME (2001) The effect of saline irrigation on Lucerne production: shoot and root growth, ion relations and flowering incidence in six cultivars grown in Northern Victoria, Australia. Irrig Sci 20:55-64

37. Forghani AH, Almodares A, Ehsanpour AA (2018) Potential objectives for gibberellic acid and paclobutrazol under salt stress in sweet sorghum (Sorghum bicolor [L.] Moench cv. Sofra). Appl Biol Chem 61(1):113-124 